\title{
XV Международное совещание по геологии россыпей и месторождений кор выветривания «Россыпи и месторождения кор выветривания: изучение, освоение, экология» (РКВ-2015)
}

\section{Б.С. Лунев ${ }^{\mathrm{a}}$, В.А. Наумов ${ }^{\mathrm{b}}$, О.Б. Наумова ${ }^{\mathrm{a}, \mathrm{b}}$, Б.М. Осовецкий ${ }^{\mathrm{a}, \mathrm{b}}$}

${ }^{a}$ Пермский государственный национальный исследовательский университет, 614990, Пермь, ул. Букирева, 15. E-mail: poisk@psu.ru

${ }^{\mathrm{b}}$ Естественнонаучный институт Пермского государственного национального исследовательского университета, 614990, Пермь, ул. Генкеля, 4 . Еmail: naumov@psu.ru

(Статья поступила в редакичю 30 августа 2015 г.)

На базе Пермского государственного национального исследовательского университета в г. Перми с 24 по 28 августа 2015 г. прошло XV Международное совещание по геологии россыпей и месторождений кор выветривания «Россыпи и месторождения кор выветривания: изучение, освоение, экология» (РКВ-2015). На совещании были представлены программные доклады по истории и результатам работы мировых научных центров, теоретические, методические и практические наработки по геологии россыпей, техногенно-минеральным образованиям за последние годы.

Ключевые слова: россыпи, коры выветривания, месторождения. DOI: 10.17072/psu.geol.28.97

На совещании зарегистрировано 217 участников, представлено 129 докладов специалистов высокой квалификации, в том числе 43 докторов и 65 кандидатов наук, из научных учреждений Российской академии наук, отраслевых институтов, вузов, других научных и производственных организаций (рис. 1). По результатам совещания подготовлены и изданы научные материалы [1].

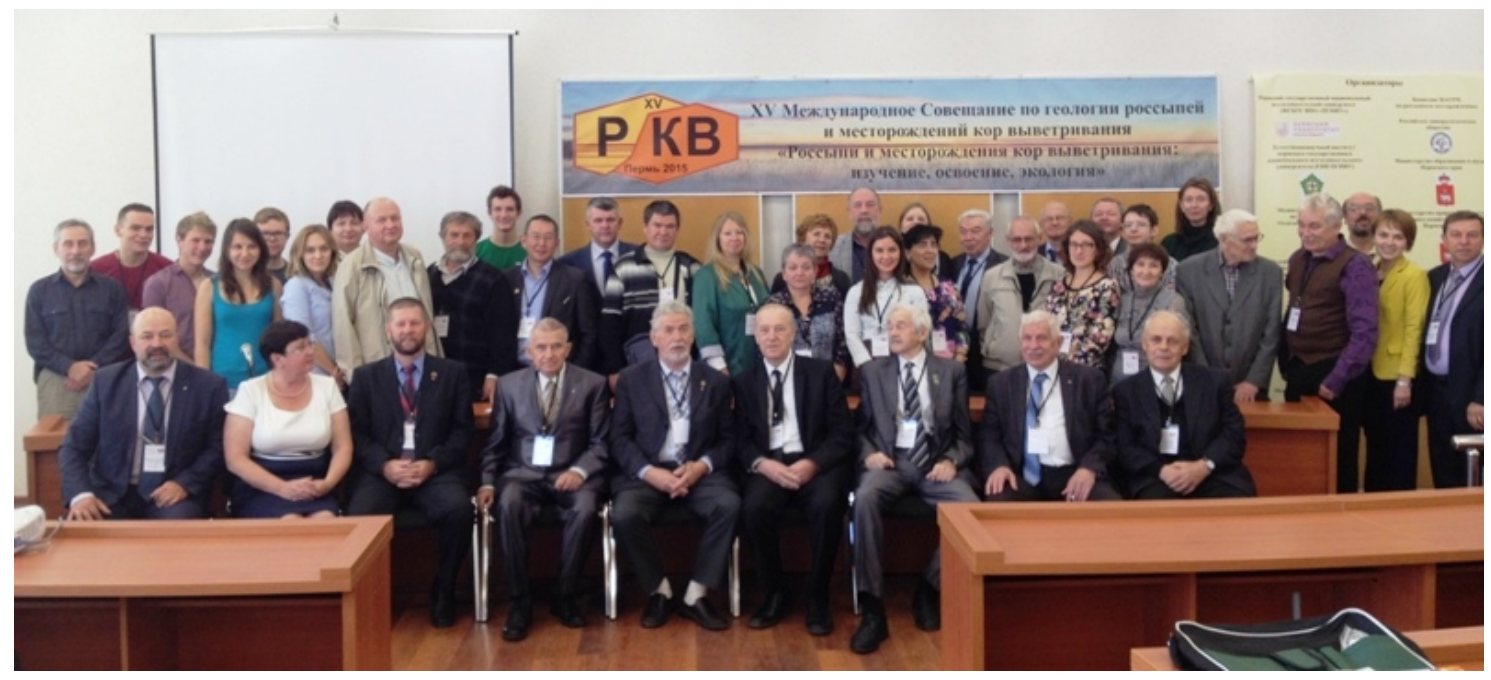

Рис. 1. Участники пленарного заседания

(C) Лунев Б.С., Наумов В.А., Наумова О.Б., Осовецкий Б.М., 2015 
Доклады были посвящены практически всем территориям России, где выявлены или разрабатываются месторождения (Карелия, Подмосковье, Таманский полуостров, Воронежская область, Урал, Тиман, Алтай, Салаир, Якутия, Тува, Хакассия, Красноярский край, Забайкалье, Приамурье, Дальний Восток) как в пределах кристаллических структур щитов, горно-складчатых областей, так и в пределах осадочного чехла ВосточноЕвропейской и Сибирской платформ, внутренних и межгорных впадин. Широко представлены доклады представителей Украины, Казахстана, Узбекистана, Азербайджана, стран дальнего зарубежья: Канады, Великобритании (рис. 2).

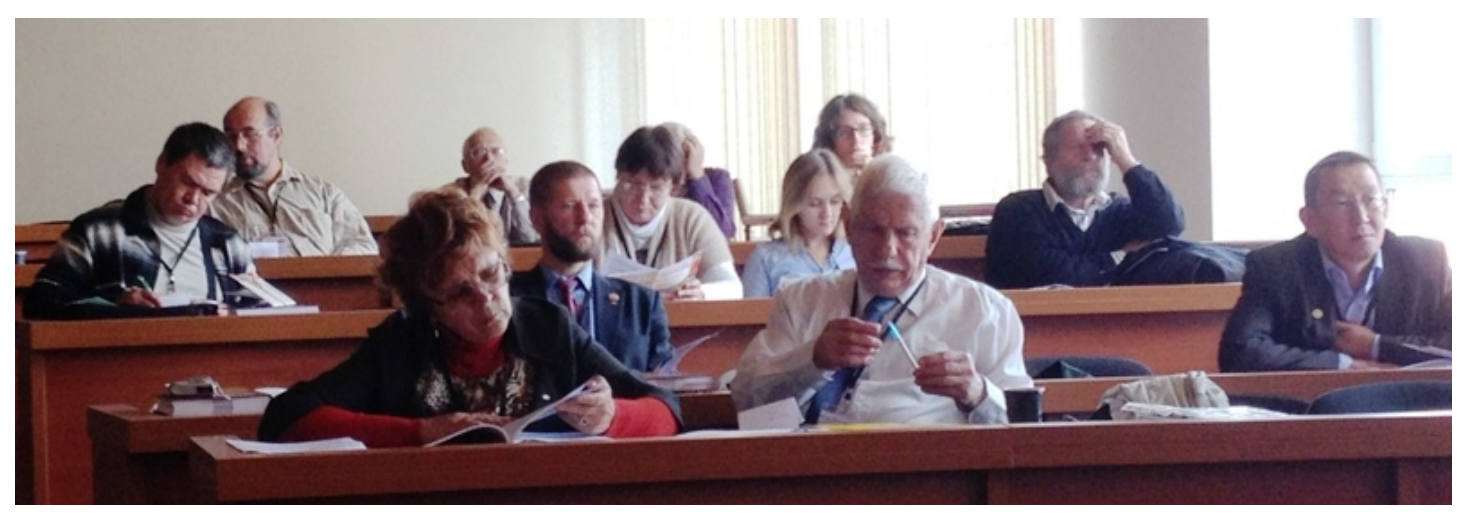

Рис. 2. Слушатели на пленарном заседании

В докладах рассмотрены вопросы современного состояния минеральносырьевой базы россыпей России и зарубежных стран и перспективы ее расширения; обсуждены проблемы развития фундаментальных направлений россыпной геологии: формирования и преобразования техногенно-минеральных образований (в т.ч. техногенных россыпей), наноминералогии россыпных металлов; минерагении кор выветривания, россыпей и техногенно-минеральных образований; источников вещества при формировании россыпей. Значительное внимание уделено совершенствованию методов технологической минералогии при освоении россыпей и изучению тонких особенностей их вещественного состава, созданию и внедрению новых методов изучения, поисков и прогнозирования, научнометодического обеспечения и практического решения геоэкологических проблем при освоении россыпей. Представлены новые данные о золотоносных, платиноносных и алмазоносных россыпях, особенностях их формирования и связи с коренными источниками.
Принимающая сторона продемонстрировала результаты научной деятельности пермской школы россыпной геологии, основанной профессором Б.С. Луневым 50 лет назад.

Участники совещания провели выездную сессию (полевую геологическую экскурсию) «Золото-алмазная колыбель России». Для ее проведения была выпущена монография с одноименным названием [2], включающая три раздела. В первом разделе приводится геологическое описание Пермского края и Свердловской области. Во втором - рассмотрены исторические аспекты и сделан анализ работ по поискам золота и алмазов в Уральском регионе (от первых открытий до современного состояния геологической отрасли). На примере Пермского края показан геологический потенциал золота в разных типах полезных ископаемых. В третьем дано краткое описание геологических объектов и памятников истории открытия рудного и россыпного золота и алмазов в России.

Автомобильный маршрут был нанесен на геологическую карту. К нему приложе- 
на таблица географических пунктов и пересекаемых по маршруту комплексов пород и тектонических структур; перечень памятников, в котором показана их связь с историческими событиями на пути следования по маршруту г. Пермь - п. Верхнечусовские Городки (памятник места открытия первой нефти Урало-Поволжья) п. Промысла - г. Невьянск - г. Березовский - г. Пермь.
На месте находки первого российского алмаза (рис. 3) участников совещания приветствовали представители регионального общественного движения «Горнозаводское направление» - жители п. Промысла и г. Горнозаводска (http://gornozavodsk.su/?p=5900). Они показали местный музей дом Грина, где жил и «старался на золоте» выдающийся писатель Александр Степанович Грин.

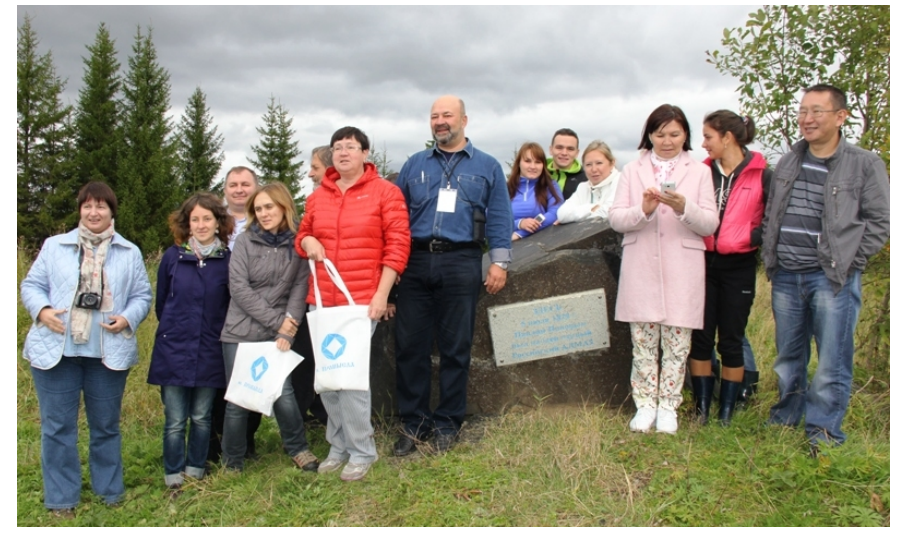

Рис. 3. Участники совещяания у памятника находке первого алмаза в России

Сотрудники ЕНИ ПГНИУ продемонстрировали работу современного геофизического оборудования для определения мощностей литологических горизонтов россыпи, приемы практического исполь- зования георадара. На р. Полуденке россыпники уральской, чукотской, сибирской, магаданской и канадской школ показали класс промывки песков (рис. 4).

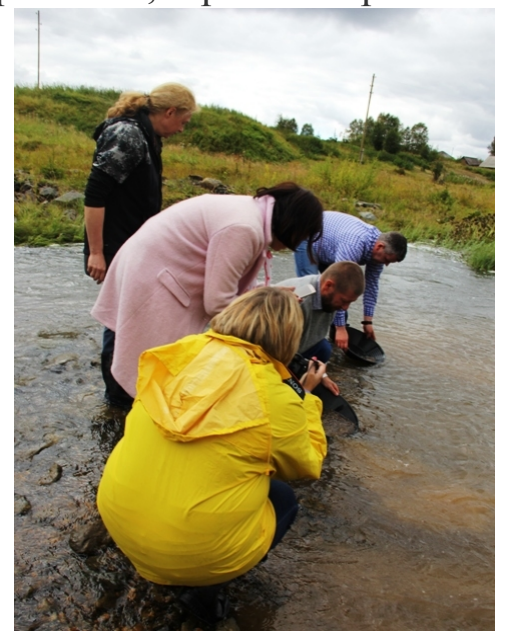

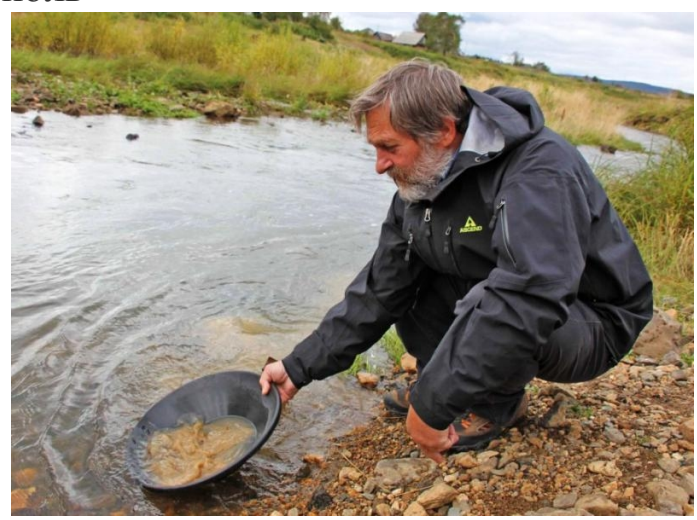

Рис. 4. Состязания по промывке песков на р. Полуденке
В г. Невьянске экскурсанты посетили знаменитую падающую башню Акинфия Демидова и познакомились со спецификой отработки россыпей старательской артелью «Нейва», в которой на практике совмещены дедовская смекалка и современные технологии.
В г. Березовске участники познакомились с уникальными экспонатами Музея золота. На территории храма Успения Пресвятой Богородицы почтили память Льва Ивановича Брусницына, нашедшего на Урале в 1814 г. первое россыпное золото. Благодаря его знаниям и подвижничеству в России научились «мыть золото из 
россыпей», а Урал стимулировал зарождение мировых золотых «лихорадок» на Клондайке, Аляске и в Австралии. В середине 19 в. Россия вышла на лидирующие позиции в мире по добыче золота.

Библиографический список

1. Россыпи и месторождения кор выветривания: изучение, освоение, экология // Матлы XV Международного совещания по геологии россыпей и месторождений кор выветривания / ред. Н.П. Лаверов, О.Б. Наумова, В.А. Наумов, Б.М. Осовецкий, Б.С. Лунев. Перм. гос. нац. исслед. ун-т. Пермь, 2015. 270 с.

2. Копьлов И.С., Наумов В.А., Наумова О.Б., Харитонов T.B. Золото-алмазная колыбель России: монография / ред. В.А. Наумов; Перм. гос. нац. исслед. ун-т. Пермь, 2015. $132 \mathrm{c}$.

\section{International Meeting on the Placers Geology and Weathering Crust Deposits «Placers and Deposits of Weathering Crusts: Study, Development, and Ecology»}

B.S. Lunev ${ }^{a}$, V.A. Naumov ${ }^{b}$, O.B. Naumova ${ }^{a}$, B.M. Osovetskiy ${ }^{a}$

${ }^{a}$ Perm State University, 15 Bukireva Str., Perm 614990, Russia

E-mail: poisk@psu.ru

Natural Sciences Institute of Perm State University, 4 Genkelya Str., Perm 614990, Russia E-mail: naumov@psu.ru

The information about the meeting dedicated to geology of placers and weathering crust deposits held in the Perm State University August 24-28, 2015 is presented.

\section{References}

1. Rossypi i mestorozhdeniya kor vyvetrivaniya: izuchenie, osvoenie, ekologiya [Placers and deposits of weathering crusts: study, development, and ecology]. Proc. XV Intern. Meet., Laverov N.P., Naumova O.B., Naumov V.A., Osovetskiy B.M., Lunev B.S. (Eds.), Perm state University, Perm, 2015, p. 270. (in Russian)

2. Kopylov I.S., Naumov V.A., Naumova O.B., Kharitonov T.V. 2015. Zoloto-almaznaya kolybel Rossii [Place of Russian gold and diamond discovery]. Perm State University Publ., Perm, p. 132 (in Russian)

\section{ВЕСТНИК ПЕРМСКОГО УНИВЕРСИТЕТА. ГЕОЛОГИЯ. 2015. ВЫПУСК 3 (28) \\ Редактор Л.Г. Подорова, корректор Л.И. Иванова \\ Подписано в печать 15.09.2015. Формат 60 х 84/8. \\ Усл. печ. л. 11,62. Тираж 500 экз. Заказ}

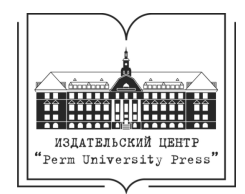

Издательский центр Пермского государственного национального исследовательского университета. 614990, г. Пермь, ул. Букирева, 15

Подписной индекс журнала «Вестник Пермского университета. Геология» в Объединенном каталоге «Пресса России» - 41002 